\title{
Human Polyomavirus Receptor Distribution in Brain Parenchyma Contrasts with Receptor Distribution in Kidney and Choroid Plexus
}

\author{
Sheila A. Haley, ${ }^{*}$ Bethany A. O'Hara, ${ }^{*}$ Christian D.S. Nelson, ${ }^{*}$ Frances L.P. Brittingham, ${ }^{*}$ Kammi J. Henriksen,
} Edward G. Stopa, ${ }^{\dagger}$ and Walter J. Atwood*

From the Departments of Molecular Biology, Cell Biology and Biochemistry* and Pathology and Laboratory Medicine, ${ }^{\dagger}$ Warren Alpert Medical School, Brown University, Providence, Rhode Island

Accepted for publication April 14, 2015.

Address correspondence to Walter J. Atwood, Ph.D., Department of Molecular Biology, Cell Biology and Biochemistry, Brown University, 70 Ship St., Providence, RI 02903. E-mail: walter_ atwood@brown.edu.

\begin{abstract}
The human polyomavirus, JCPyV, is the causative agent of progressive multifocal leukoencephalopathy, a rare demyelinating disease that occurs in the setting of prolonged immunosuppression. After initial asymptomatic infection, the virus establishes lifelong persistence in the kidney and possibly other extraneural sites. In rare instances, the virus traffics to the central nervous system, where oligodendrocytes, astrocytes, and glial precursors are susceptible to lytic infection, resulting in progressive multifocal leukoencephalopathy. The mechanisms by which the virus traffics to the central nervous system from peripheral sites remain unknown. Lactoseries tetrasaccharide c (LSTc), a pentasaccharide containing a terminal $\alpha 2,6$-linked sialic acid, is the major attachment receptor for polyomavirus. In addition to LSTc, type 2 serotonin receptors are required for facilitating virus entry into susceptible cells. We studied the distribution of virus receptors in kidney and brain using lectins, antibodies, and labeled virus. The distribution of LSTc, serotonin receptors, and virus binding sites overlapped in kidney and in the choroid plexus. In brain parenchyma, serotonin receptors were expressed on oligodendrocytes and astrocytes, but these cells were negative for LSTc and did not bind virus. LSTc was instead found on microglia and vascular endothelium, to which virus bound abundantly. Receptor distribution was not changed in the brains of patients with progressive multifocal leukoencephalopathy. Virus infection of oligodendrocytes and astrocytes during disease progression is LSTc independent. (Am J Pathol 2015, 185: 2246-2258; http://dx.doi.org/10.1016/j.ajpath.2015.04.003)
\end{abstract}

The human polyomavirus (JCPyV) is the causative agent of progressive multifocal leukoencephalopathy (PML), a rapidly progressing, often fatal neurodegenerative disease. Although PML is rare, JCPyV infection is widespread, infecting approximately $50 \%$ to $80 \%$ of the healthy adult population. ${ }^{1,2}$ As the initial infection is asymptomatic, the mode of JCPyV transmission is unknown. The virus establishes a persistent infection in the kidney and urinary tract of immunocompetent hosts, ${ }^{3}$ and about $20 \%$ of these infected individuals shed virus in their urine. ${ }^{4}$ JCPyV DNA has also been detected in other tissues, including B lymphocytes in the bone marrow, tonsillar stromal cells, lungs, spleen, and brain, ${ }^{5-13}$ suggesting additional sites of viral persistence. The route of viral transmission from the initial site(s) of infection and latency to the central nervous system (CNS), the main site of pathogenesis, is not clearly understood.
Under conditions of immunosuppression, JCPyV infects and destroys the myelin-producing oligodendrocytes, resulting in demyelination, which is the hallmark of this fatal disease; to a

Supported by NIH grants R01NS043097 (W.J.A.) and P01NS065719 (W.J.A.). Core facilities at Brown are supported by NIH grant P30GM103410 (W.J.A.). Progressive multifocal leukoencephalopathy brain tissues were obtained via funding through the National Institute of Mental Health and the National Institute of Neurological Disorders and Stroke (the Manhattan HIV Brain Bank: U01MH083501 and R24MH59724; the Texas NeuroAIDS Research Center: U0MH083507 and R24NS45491; and the California NeuroAIDS Tissue Network: U0MH083506 and R24MH59745).

The content of this work is solely the responsibility of the authors and does not necessarily represent the official view of the National NeuroAIDS Tissue Consortium or the NIH.

Disclosures: None declared.

Current address of K.J.H., Department of Pathology, University of Chicago Pritzker School of Medicine, Chicago, IL. 
lesser degree, astrocytes and neurons are infected as well. ${ }^{14,15}$ When PML was first described, it was a rare disease that primarily affected patients with B-cell lymphoproliferative disorders. ${ }^{16,17}$ During the AIDS pandemic, the prevalence of PML in patients rose significantly, with $3 \%$ to $5 \%$ of HIV/AIDS patients developing PML. ${ }^{18,19}$ With the advent of combined antiretroviral therapy, the number of HIV/AIDS patients with PML has declined, although it has decreased less significantly than that of other opportunistic infections. ${ }^{20}$ While the occurrence of PML historically has been linked to HIV/AIDS, recently the rate of PML has risen again with the introduction of immunomodulatory therapy for autoimmune diseases, such as multiple sclerosis, rheumatoid arthritis, psoriasis, and Crohn disease. ${ }^{21-25}$ PML has been reported to occur in patients receiving treatment with drugs including the monoclonal antibodies natalizumab, efalizumab, and rituximab. ${ }^{22,26}$ One action of these therapies is to inhibit leukocyte migration into the CNS, suggesting that a key to JCPyV pathogenesis in the brain is the suppression of cells that normally perform immune surveillance. In addition to PML, JCPyV causes other diseases of the CNS, including JCPyV granule cell neuronopathy ${ }^{27}$ and JCPyV encephalopathy, ${ }^{28}$ and has been associated with isolated cases of JCPyV-associated nephropathy in kidney transplant recipients. ${ }^{29-32}$

JCPyV has a circular, double-stranded DNA genome that is enclosed by a nonenveloped, icosahedral capsid, which is composed of three proteins, viral proteins (VP)-1, -2 , and $-3 .^{33}$ VP1 is the main component of the capsid and is the primary means by which the virus engages receptors to initiate infection of host cells.

JCPyV requires at least two known functional receptors for attachment and subsequent entry. Previous in vitro experiments have demonstrated that the virus initially binds to an $\alpha 2,6$ sialic acid on the cell surface. ${ }^{34-36}$ Crystallographic and functional studies with VP1 demonstrated that JCPyV VP1 binds to the host cell via the $\alpha 2,6$-linked glycan lactoseries tetrasaccharide $\mathrm{c}$ (LSTc) ${ }^{37}$ Although LSTc recognition is required for JCPyV attachment, it is not sufficient for viral infection. In addition to engaging LSTc on the cell surface, JCPyV entry requires the presence of a serotonin (5-HT)-2 receptor family member. Virus internalization in a nonpermissive cell line was markedly enhanced when the cell line was transfected with any of the three $5-\mathrm{HT}_{2}$ receptor family subtypes, $5-\mathrm{HT}_{2 \mathrm{~A}}, 5-\mathrm{HT}_{2 \mathrm{~B}}$, or $5-\mathrm{HT}_{2 \mathrm{C}}$, and shown to act early in the virus life cycle by facilitating virus entry. ${ }^{38,39}$ JCPyV infection is blocked by antibodies to $5-\mathrm{HT}_{2} \mathrm{~s}$ and other specific inhibitors of these receptors.

Despite JCPyV being a significant human pathogen, many questions about its etiology remain unresolved. The species specificity of JCPyV is highly restricted to humans, an obstacle that has stymied efforts to develop an animal model to follow the path of the virus from initial infection to CNS penetration.

The current study focused on identifying determinants of tissue tropism of JCPyV in two known sites of JCPyV infection, the brain and the kidney, using labeled virus, and identified receptors as markers to trace $\mathrm{JCPyV}$ interaction with specific cell types in the human host. This work has relevance in understanding the basic mechanism by which JCPyV engages its target cell(s) in the host and its route to the CNS, as well as clinical interest in that it suggests possibilities for specific interference of infection.

\section{Materials and Methods}

\section{Virus Purification and Labeling}

Generation of the JCPyV virus strain Mad-1/SVE $\Delta$ has been described previously. ${ }^{40,41}$ Purified JCPyV was labeled with Alexa Fluor 488 (Invitrogen, Carlsbad, CA) according to the manufacturer's instructions. Labeled virus was added to kidney sections at concentrations of 2 and $20 \mu \mathrm{g} / \mathrm{mL}$ on brain sections.

\section{Tissue Preparation and IHC Staining}

Human brain (from frontal and parietal lobe), choroid plexus, meningeal, and kidney tissues (Table 1) were obtained from the National NeuroAIDS Tissue Consortium ${ }^{42}$ and from Rhode Island Hospital (Providence, RI) in accordance with protocols approved by the Institutional Review Boards at Brown University (Providence, RI) and Rhode Island Hospital. Neural tissues selected as normal controls were from patients who were HIV-seronegative and died of causes not related to HIV/AIDS. Formalin-fixed, paraffin-embedded slides were deparaffinized in xylene followed by a series of graded ethanol washes and subjected to sodium citrate antigen retrieval if necessary. Freshfrozen brain tissues were embedded in OCT, sectioned, and fixed for 10 minutes in $70 \%$ acetone and $30 \%$ ethanol at $4{ }^{\circ} \mathrm{C}$ before staining. Sections were stained with antibodies against mucin (MUC)-1 (sc-53377; Santa Cruz Biotechnology, Dallas, TX), 5- $\mathrm{HT}_{2 \mathrm{~A}}$ [S1001-16 (US Biological, Salem, MA) and LSA1106 (LSBio, Seattle, WA)], 5-HT 2 В [S-1001-17A (US Biological) and HPA012867 (Sigma, St. Louis, MO)], 5-HT $2 \mathrm{C}$ [AB9507 (Millipore, Billerica, MA) and LS-A1119 (LSBio)], T antigen (Ab-2; Millipore), JCPyV VP1 (pAb 597 $7^{43}$; gifted by Dr. Edward Harlow, Harvard Medical School, Boston, MA), carbonic anhydrase $\mathrm{II}^{44}$ (PC076; The Binding Site, Birmingham, UK), glial fibrillary acidic protein (G-A-5; Sigma), OLIG2 (MABN50; Millipore), and CD68 (Cell Marque, Rocklin, CA). For immunofluorescence detection, slides were then incubated in secondary antibody conjugated to Alexa Fluor 488 or 594 at $10 \mu \mathrm{g} / \mathrm{mL}$ (Invitrogen) and mounted in media containing DAPI (Vector Laboratories, Burlingame, CA). For lectin staining, slides were blocked with carbohydratefree blocking solution and streptavidin/biotin block (Vector Laboratories) and incubated with biotinylated Polyporus squamosus lectin (PSL) at $20 \mu \mathrm{g} / \mathrm{mL}$ (E-Y Laboratories, San Mateo, CA), followed by streptavidin conjugated to Alexa Fluor 488 or 594 at $3.3 \mu \mathrm{g} / \mathrm{mL}$ (Vector Laboratories). For immunohistochemistry, primary antibody incubation slides were stained with ImmPRESS Universal secondary antibody (Vector Laboratories) and developed using the DAB system 
Table 1 Human Patient Information

\begin{tabular}{lllllllll}
\hline Subject & Tissue type & Age & Sex & Race & HIV & PML & Pathology & Cause of death \\
\hline 1 & Brain & 36 & M & W & + & + & PML & HIV/AIDS \\
2 & Brain & 30 & M & W & + & + & PML & HIV/AIDS \\
3 & Brain & 51 & M & W & + & + & PML & HIV/AIDS \\
4 & Brain & 47 & M & W & + & + & PML & HIV/AIDS \\
5 & Brain & 46 & M & NR & + & + & PML & HIV/AIDS \\
6 & Brain & 39 & F & NR & + & + & PML & HIV/AIDS \\
7 & Brain & 43 & M & NR & + & + & PML & HIV/AIDS \\
8 & Brain & 45 & M & NR & + & + & PML & PML \\
9 & Brain & 84 & M & NR & - & + & PML & PML \\
10 & Brain & 64 & F & W & - & + & PML & HIV/AIDS \\
11 & Brain & 44 & M & W & + & - & HIV no E & HIV/AIDS \\
12 & Brain & 46 & M & W & + & - & HIV no E & HIV/AIDS \\
13 & Brain & 48 & M & W & + & - & Normal & Myocardial infarction \\
14 & Brain & 69 & F & W & - & - & Normal & Myocardial infarction \\
15 & Brain & 57 & M & W & - & - & Normal & Cardiac arrhythmia \\
16 & Brain & 59 & M & W & - & - & Normal \\
17 & Kidney & 50 & M & W & - & - & Normal \\
18 & Kidney & 67 & F & W & - & - & Normal \\
19 & Kidney & 41 & F & W & - & - & Normal \\
20 & Kidney & 32 & M & W & - & - & NA \\
\hline
\end{tabular}

F, female; M, male; HIV no E, HIV-positive patient with no observed encephalopathy; NA, not applicable; NR, not recorded; PML, progressive multifocal leukoencephalopathy; W, white.

(Vector Laboratories) according to the manufacturer's protocol. Slides were then counterstained with hematoxylin. To determine areas of demyelination, PML tissue sections were deparaffinized as described in Tissue Preparation and IHC Staining, then incubated in Luxol fast blue solution (Sigma) for 2 hours at $60^{\circ} \mathrm{C}$. Slides were decolorized in ethanol and then differentiated in saturated lithium carbonate. The samples were then counterstained with hematoxylin and eosin. Tissues were analyzed using an Eclipse E800 microscope (Nikon, Melville, NY) equipped with an ORCA-ER digital camera (Hamamatsu
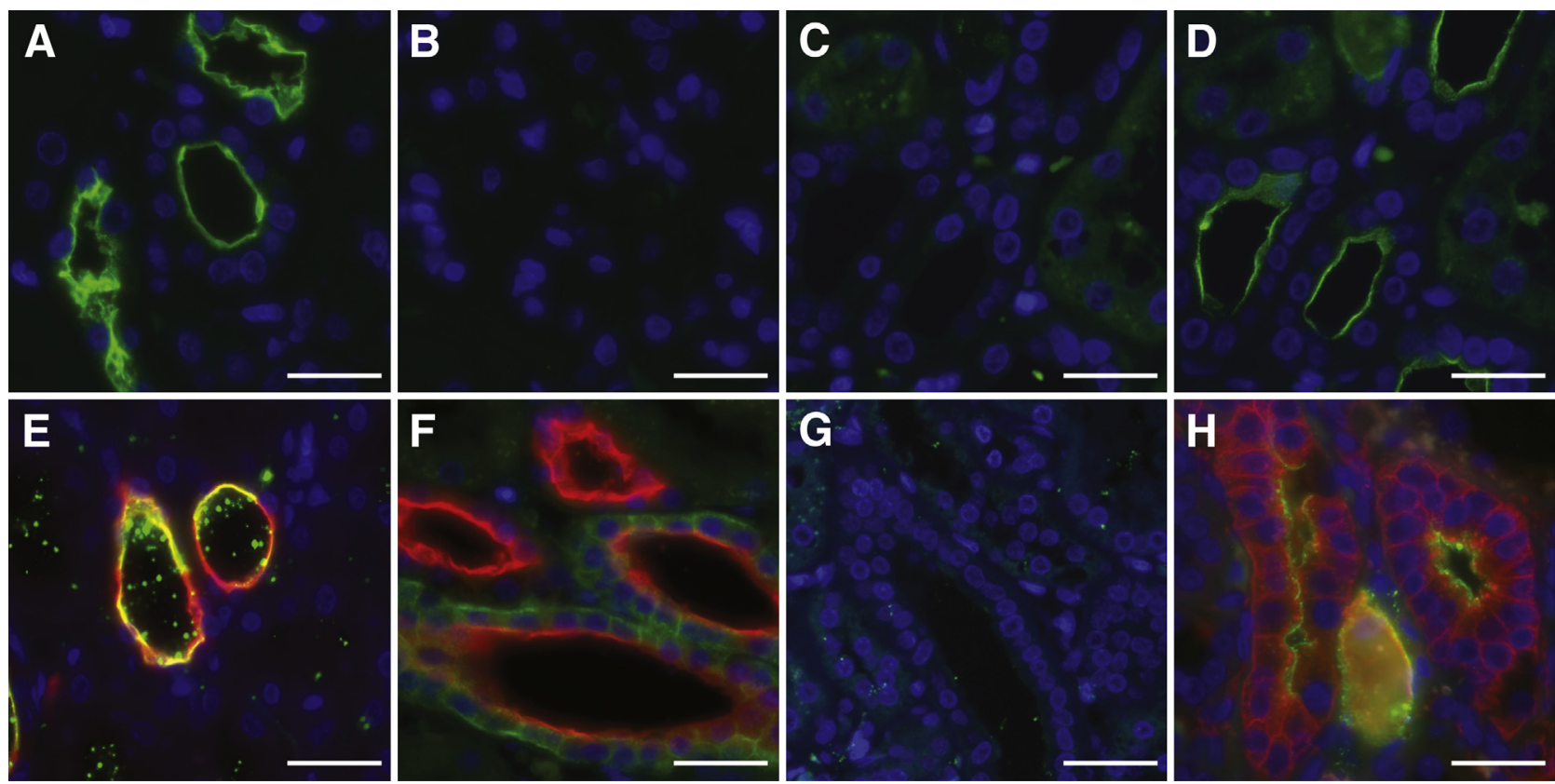

Figure 1 Attachment of the human polyomavirus (JCPyV) to kidney tubules is mediated by lactoseries tetrasaccharide C (LSTc). A: Immunofluorescence detection shows that JCPyV-488 (green; DAPI stained nuclei, blue) binds to the apical side of kidney tubules. B: Removal of sialic acid binding sites with neuraminidase abolishes JCPyV binding. C and D: LSTc pretreatment inhibits JCPyV binding (C), whereas in a serial section (D) LSTb pretreatment has no effect on JCPyV attachment to tubules. E: Colocalization analysis with the marker MUC-1 (red) demonstrates that JCPyV-488 (green) specifically binds to distal tubules and collecting ducts of the kidney. F: Polyporus squamosus lectin (PSL), a lectin recognizing the terminal trisaccharide of LSTc, labels distal tubules and collecting ducts (PSL, green; MUC1, red). G: PSL label is removed with neuraminidase. H: JCPyV (green) colocalizes with the lectin PSL (red). Scale bars: $25 \mu \mathrm{m}$. 

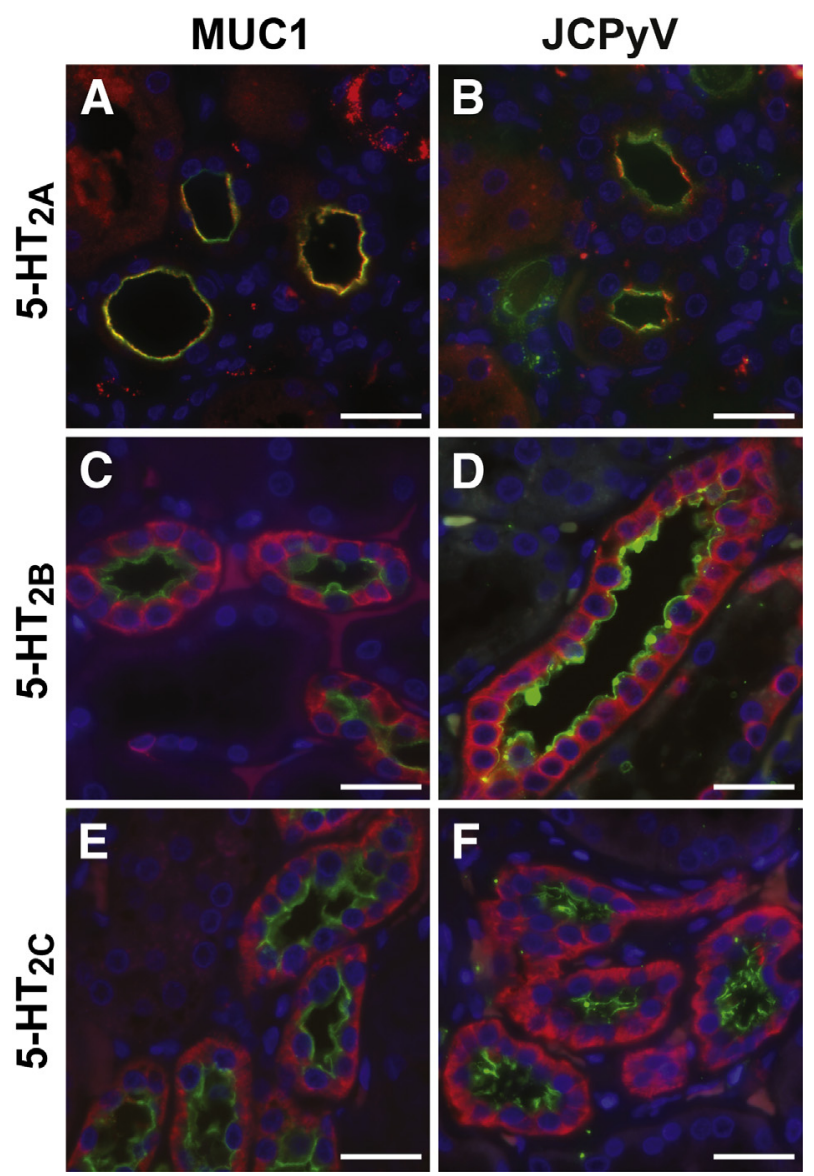

Figure 2 Viral entry receptor expression and human polyomavirus (JCPyV) binding to kidney distal tubules. Double immunofluorescence analysis demonstrates that virus entry receptors serotonin (5-HT) $2 \mathrm{~A}(\mathrm{~A})$, $5-\mathrm{HT}_{2 \mathrm{~B}}(\mathbf{C})$, and $5-\mathrm{HT}_{2 \mathrm{C}}(\mathrm{E})$ (red) colocalize with distal tubule and collecting duct marker MUC-1 (green). B, D, and $\mathbf{F}$ show that labeled JCPyV (green) colocalizes with each of the $5-\mathrm{HT}_{2}$ receptor family members: $5-\mathrm{HT}_{2 \mathrm{~A}}(\mathbf{B}), 5-$ $\mathrm{HT}_{2 \mathrm{~B}}$ (D), and $5-\mathrm{HT}_{2 \mathrm{C}}(\mathbf{F})$ (red). Scale bars: $25 \mu \mathrm{m}$.

Photonics KK, Hamamatsu, Japan) and OpenLAB software version 5.5.1 (Agilent Technologies, Santa Clara, CA).

\section{Neuraminidase Treatment}

Slides were rehydrated and then incubated in Neuraminidase Type V from Clostridia perfringens (Sigma) at $1 \mathrm{U} / \mathrm{mL}$ in phosphate-buffered saline supplemented with $1 \mathrm{mmol} / \mathrm{L} \mathrm{CaCl}_{2}$ and $1 \mathrm{mmol} / \mathrm{L} \mathrm{MgCl}_{2}\left(\mathrm{pH} \mathrm{6.0)}\right.$ ) for 1 hour at $37^{\circ} \mathrm{C}$ before blocking and incubation with lectin or virus.

\section{LSTb/LSTc Competition}

JCPyV-488 was preincubated with either $10 \mathrm{mmol} / \mathrm{L}$ of LSTb or LSTc (V labs, Covington, LA) in phosphatebuffered saline for 2 hours on ice, with mixing every 15 minutes $(1 \mu \mathrm{g} / \mathrm{mL}$ final virus concentration). The JCPyV-LST complexes were then added to tissue sections that had been rehydrated and blocked as described in Tissue Preparation and IHC Staining and incubated overnight at $4^{\circ} \mathrm{C}$. Slides were then washed in FTA hemagglutination buffer (Becton Dickinson, Franklin Lakes, NJ) and analyzed for virus binding by immunofluorescence.

\section{Results}

JCPyV Specifically Binds to the Distal Tubules and Collecting Ducts of the Normal Human Kidney via Interaction with LSTC

Incubation of kidney tissues with fluorescently labeled JCPyV demonstrated virus attachment to the apical side of tubules (Figure 1A). This binding was mediated by sialic acid, as pretreatment of the tissue with neuraminidase inhibited binding by removing the sialic acid terminal sugars from the cell surface (Figure 1B). It is known that JCPyV specifically binds to the sialic acid pentasaccharide LSTc. ${ }^{37}$ To test whether the binding is specific for LSTc, the virus was preincubated with LSTc before addition to tissue samples. This pretreatment also inhibited virus binding (Figure 1C). If however the virus was preincubated with LSTb, no inhibition of virus attachment was observed (Figure 1D). LSTb is identical to LSTc in molecular weight and composition but features a branching rather than linear $\alpha 2,6$-linked sialic acid. Therefore, JCPyV binding to the kidney tissue is likely mediated by sialic acid interactions, specifically with LSTc. The preferential binding sites of JCPyV in the kidney were distal tubules and collecting ducts, as shown by colocalization of the virus with the marker MUC1 (Figure 1E). ${ }^{45,46}$ JCPyV binding was observed in these tubules in both the medulla and cortex of the kidney. Although some MUC1 ${ }^{+}$tubules did not appear to be bound by $\mathrm{JCPyV}$, we did not observe $\mathrm{JCPyV}^{+}$tubules that were $\mathrm{MUC1}^{-}$. On extended incubation times and high virus concentration, a small amount of virus binding to Bowman's capsule, to endothelial cells of the glomeruli, and to proximal tubules could be observed, but this binding was minor compared with that to the collecting ducts and distal tubules.

The nature of JCPyV binding to the kidney was further analyzed using PSL, a lectin from the mushroom Polyporus squamosus. PSL has high specificity toward nonreducing terminal Neu5Ac $\alpha 2,6 \mathrm{Gal} \beta 1,4 \mathrm{GlcNAc}$, the terminal trisaccharide sequence of $\mathrm{LSTc}^{47,48}$ of asparagine-linked $(\mathrm{N}$ linked) oligosaccharides. PSL is more specific than is the more commonly used Sambucus nigra lectin, which also detects terminal $\alpha 2,6$-linked $N$-acetylneuraminic acid present on serine/threonine-linked oligosaccharides. ${ }^{49}$ In the kidney, PSL exhibits a binding profile broader than that of JCPyV, binding to the distal tubules and collecting ducts, glomeruli, and endothelium. JCPyV bound mostly to the apical side of the tubules, whereas PSL labeled the basal and lateral sides of these cells as well. Neuraminidase treatment removed lectin binding sites (Figure 1G). This finding demonstrated that an $\alpha 2,6$ sugar closely related to LSTc was on the kidney structures to which JCPyV bound, especially 

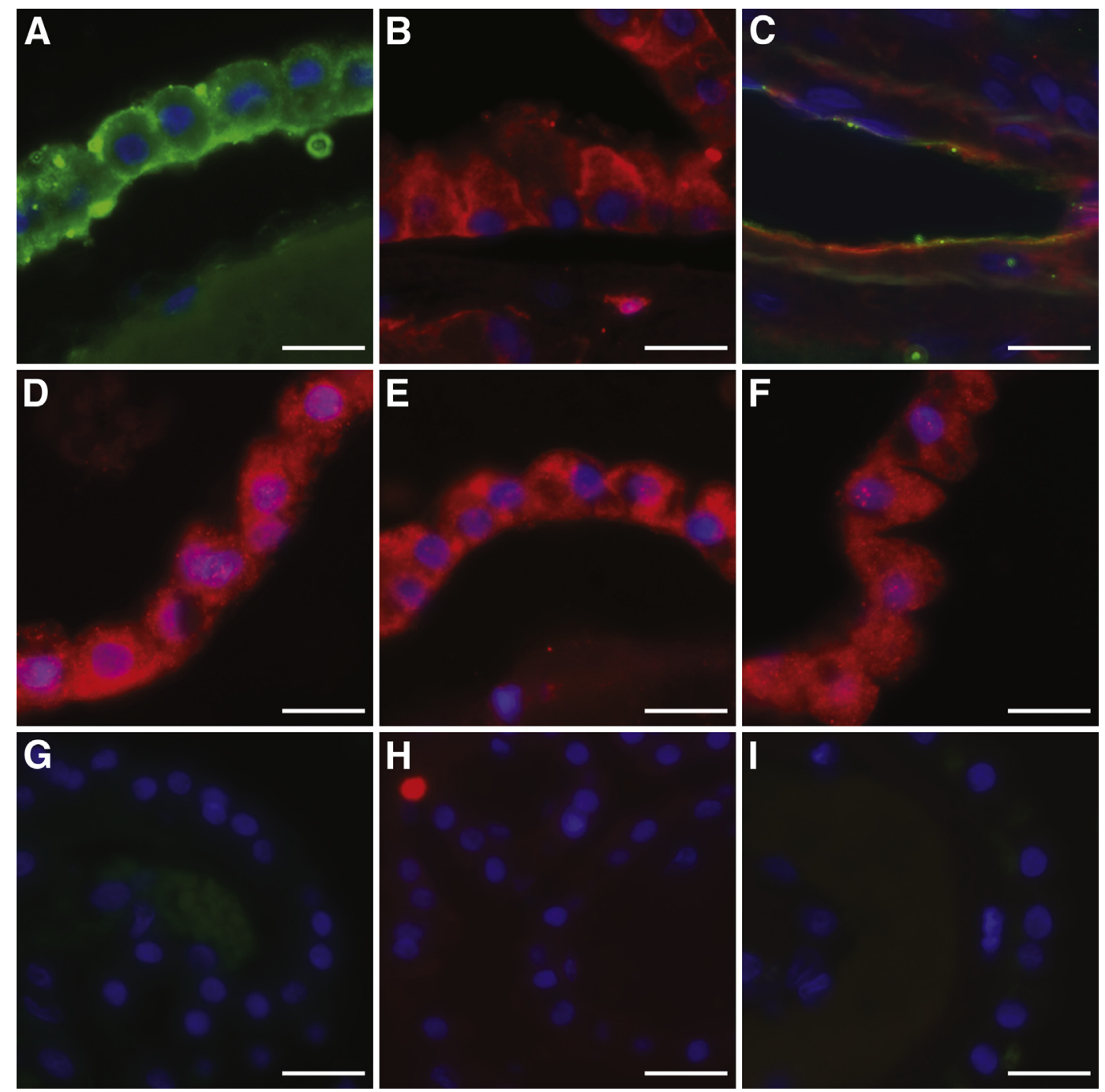

Figure 3 Human polyomavirus (JCPyV) receptor expression and virus binding in the choroid plexus. A: JCPyV-488 (green) binding to choroid plexus epithelium. B: Polyporus squamosus lectin (PSL; red) binding to choroid plexus. C: JCPyV-488 (green) and PSL (red) colocalize to blood vessels in the choroid plexus. Serotonin (5-HT) $2 \mathrm{~A}(\mathbf{D}), 5-\mathrm{HT}_{2 \mathrm{~B}}(\mathbf{E})$, and $5-\mathrm{HT}_{2 \mathrm{C}}(\mathrm{red})(\mathbf{F})$ are expressed in choroid plexus epithelium. G: Treatment of choroid plexus with neuraminidase removes JCPyV binding sites. H: PSL binding is abolished following neuraminidase treatment. I: Secondary antibody only. Scale bars: $25 \mu \mathrm{m}$.

the distal tubules and collecting ducts (Figure 1, F and G). JCPyV and PSL colocalized on the same kidney distal tubules and collecting ducts. There were occasionally $\mathrm{PSL}^{+}$ tubules that were $\mathrm{JCPyV}^{-}$but not $\mathrm{PSL}^{-}$tubules that were $\mathrm{JCPyV}^{+}$(Figure $\left.1 \mathrm{H}\right)$.

In addition to the sialic acid motif necessary for specific JCPyV attachment to cells, the 5- $\mathrm{HT}_{2}$ family of 5-HT receptors were also expressed on the distal tubules and collecting ducts of the normal human kidney (Figure 2). It is known that the 5- $\mathrm{HT}_{2}$ family of receptors is the functional receptor for JCPyV entry into cells. ${ }^{38,39,50}$ All three 5-HT family members colocalized with MUC1 on the collecting ducts and distal tubules of the kidney (Figure 2, A, C, and E). 5-HT $2 \mathrm{~A}$ appears specifically on the apical side of the tubules, whereas $5-\mathrm{HT}_{2 \mathrm{~B}}$ and $5-\mathrm{HT}_{2 \mathrm{C}}$ also label the basolateral sides. Fluorescently labeled JCPyV also colocalized in the kidney with $5-\mathrm{HT}_{2 \mathrm{~A}}, 5-\mathrm{HT}_{2 \mathrm{~B}}$, and $5-\mathrm{HT}_{2 \mathrm{C}}$ (Figure 2, $\mathrm{B}, \mathrm{D}$, and F).

\section{JCPyV Specifically Binds to Choroid Plexus Epithelium and Meninges}

Similar to those of the distal tubules of the kidney, the cells of the choroid plexus epithelium (CPE) and the meninges expressed both the attachment and entry receptors for JCPyV. Labeled JCPyV bound to the apical and basolateral sides of the CPE (Figure 3A), and this attachment was dependent on the presence of sialic acid as neuraminidase treatment removed virus binding sites (Figure 3G). PSL also bound to CPE (Figure 3B), and the binding was sialic acid-dependent as it was abolished by neuraminidase (Figure $3 \mathrm{H}$ ). The CPE also expressed all three of the 5- $\mathrm{HT}_{2}$ receptors (Figure 3, D-F and I). In addition to the CPE, JCPyV bound to the blood vessels in the choroid plexus and colocalized with PSL binding (Figure 3C). In the meninges, JCPyV bound to sialic acid receptors on meningeal cells (Figure 4, A, E, and G). Meningeal cells also expressed the 

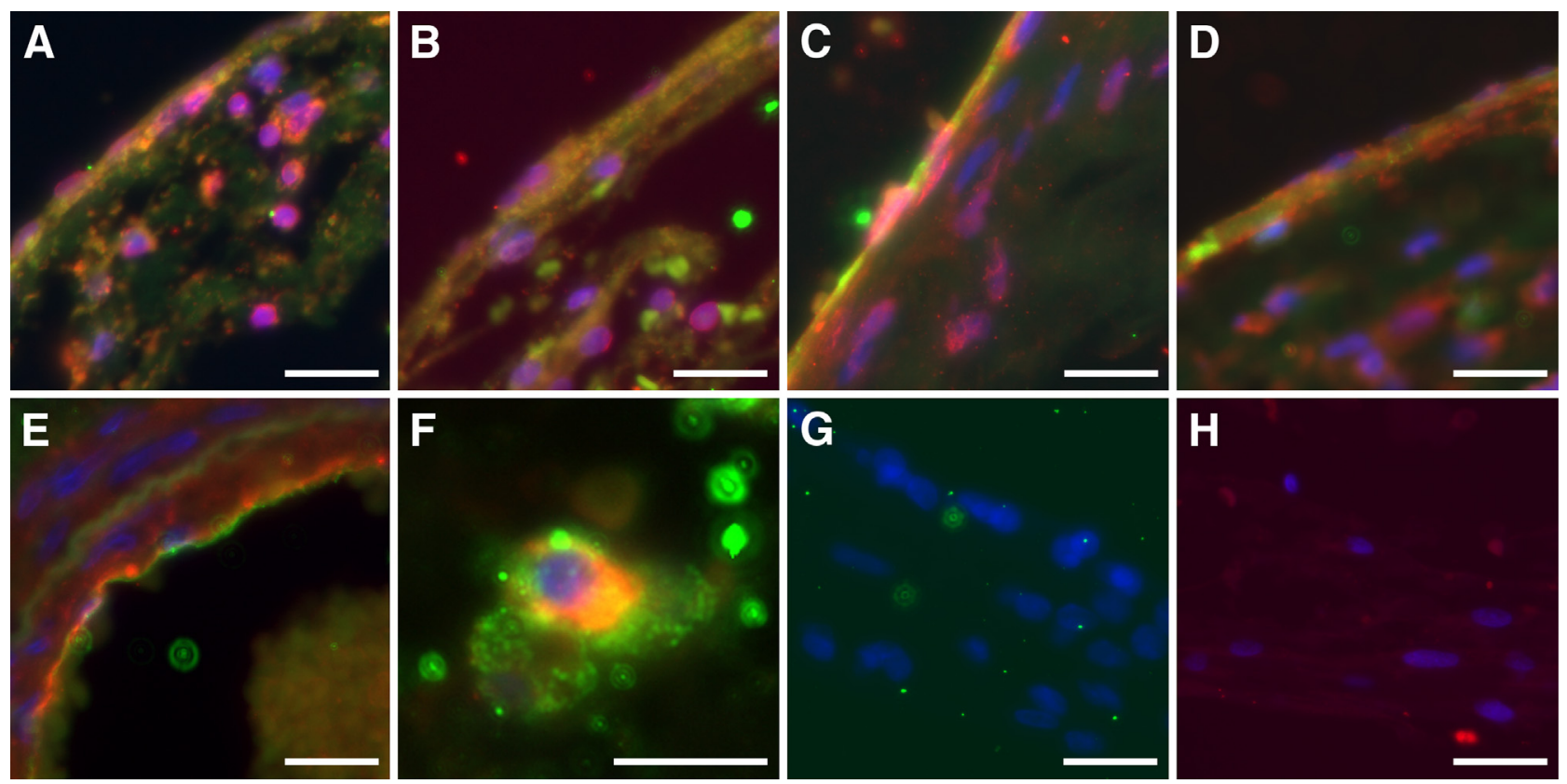

Figure 4 Human polyomavirus (JCPyV) receptor expression and virus binding in the meninges. Colocalization of JCPyV with Polyporus squamosus lectin (PSL) (A), serotonin (5-HT) 2A (B), 5- $\mathrm{HT}_{2 \mathrm{~B}}(\mathbf{C})$, and 5- $\mathrm{HT}_{2 \mathrm{C}}$ (D). E: JCPyV-488 (green) and PSL (red) colocalize to blood vessels in the meninges. F: A CD68 ${ }^{+}$cell (red) in the stroma of the meninges is bound by JCPyV-488 (green). G: Neuraminidase treatment removes JCPyV binding sites. H: Secondary antibody only. Scale bars: $25 \mu \mathrm{m}(\mathbf{A}-\mathbf{E}, \mathbf{G}$ and $\mathbf{H}) ; 10 \mu \mathrm{m}(\mathbf{F})$.

three members of the 5- $\mathrm{HT}_{2}$ subtypes (Figure 4, B-D and $\mathrm{H})$. The virus bound to the meningeal vessels (Figure 4E) as well as to $\mathrm{CD}^{+} 8^{+}$cells in the stroma (Figure 4F).

JCPyV Specifically Binds to LSTc ${ }^{+}$Microglial Cells and Brain Vascular Endothelial Cells But Not to Oligodendrocytes or Astrocytes that Are LSTc ${ }^{-}$But 5-HT Receptor ${ }^{+}$

In contrast to the kidney and choroid plexus, JCPyV attachment and entry receptors were expressed on different glial cells in human brain parenchyma, as summarized in Table 2. Oligodendrocytes expressed $5-\mathrm{HT}_{2 \mathrm{~B}}$ and $5-\mathrm{HT}_{2 \mathrm{C}}$ and were $\mathrm{LSTc}^{-}$(Figure 5, A, D, G, and J). Astrocytes expressed $5-\mathrm{HT}_{2 \mathrm{~A}}$ and $5-\mathrm{HT}_{2 \mathrm{~B}}$ but were $5-\mathrm{HT}_{2 \mathrm{C}}$ and $\mathrm{LSTc}^{-}$ (Figure 5, B, E, H, and K). Microglia, on the other hand, did not appear to express any of the $5-\mathrm{HT}_{2}$ family members but had abundant LSTc-like sugar on their surfaces (Figure 5, C, F, I and L and Figure 6A). JCPyV bound only to the $\mathrm{LSTc}^{+}$ microglial cells and brain endothelial cells (Figure 6A), consistent with the observation that LSTc is the primary attachment receptor for the virus. Treatment of the brain tissue with neuraminidase eliminated virus binding (Figure 6B). These interactions were specific for LSTc, as virus binding was unaffected by preincubation with LSTb, but virus binding was abolished by competition with LSTc (Figure 6, C and D). PSL labeling of microglia and neuroendothelium was also removed by neuraminidase (Figure 6, E and F). Virus attachment and receptor expression patterns were the same in both formalin-fixed, paraffin-embedded and fresh-frozen brain tissues (Supplemental Figure S1).

\section{JCPyV Attachment and Entry Receptor Expression in PML Brain}

Sections of brain parenchyma from patients with PML were treated with Luxol fast blue staining for the visualization of demyelinated lesions. The sections were also analyzed for virus binding to cells in the lesions as well as virus attachment and entry receptors expressed by specific cell types,

Table 2 Summary of Receptor Expression and JCPyV Attachment in Brain Parenchyma

\begin{tabular}{|c|c|c|c|c|c|}
\hline Receptor & Oligodendrocyte & Astrocyte & Neuron & Microglia & Neuroendothelium \\
\hline $5-\mathrm{HT}_{2 \mathrm{~A}}$ & - & + & + & - & - \\
\hline $5-\mathrm{HT}_{2 \mathrm{~B}}$ & + & + & + & - & - \\
\hline PSL & - & - & - & + & + \\
\hline JCPyV & - & - & - & + & + \\
\hline
\end{tabular}

JCPyV, human polyomavirus; PSL, Polyporus squamosus lectin. 


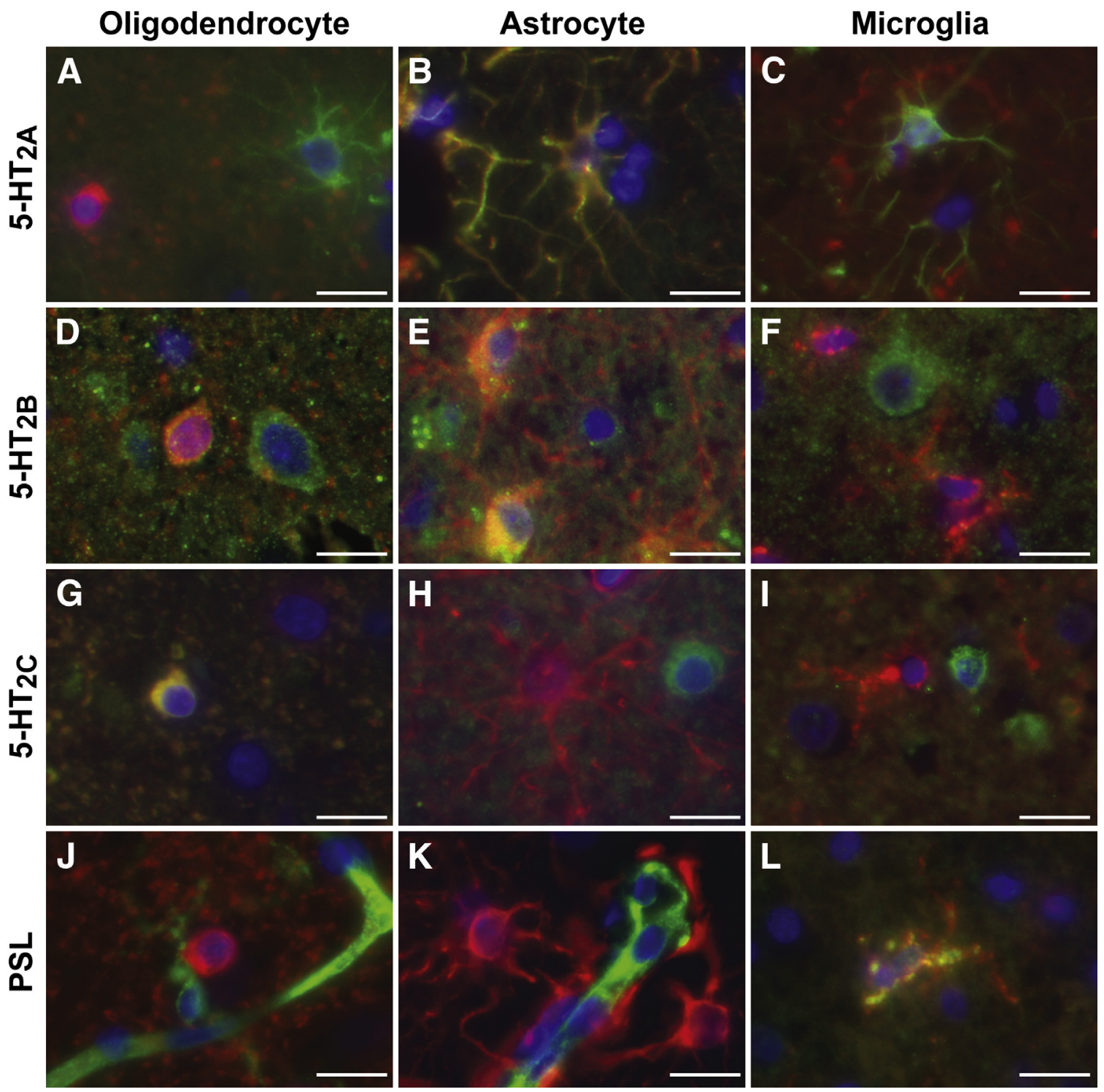

Figure 5 Glial cell type-specific expression of human polyomavirus (JCPyV) attachment and entry receptors in the brain. JCPyV entry receptors serotonin (5-HT) 2A, 2B, and 2C, and attachment receptor marker Polyporus squamosus lectin (PSL) (green) colabel with glial cell type markers carbonic anhydrase II (oligodendrocyte) (A, D, G, and J), glial fibrillary acidic protein (astrocyte) (B, E, H, and K), and CD68 (microglia) (C, F, I, and L) (red). Scale bars: $25 \mu \mathrm{m}$.

using immunohistochemistry analysis. The lesions were readily discernable (Figure 7, A and G), and the expression of LSTc as determined by PSL binding was restricted to microglia and monocyte or macrophage cells infiltrating the lesions (Figure 7, B-D). Virus bound only to $\mathrm{LSTc}^{+}$ microglial cells and infiltrating monocytes or macrophages and did not bind to the $\mathrm{LSTc}^{-}$oligodendrocytes or astrocytes (Figure 7, E and F). This finding is consistent with the role that LSTc plays in attachment but it is inconsistent with the fact that virus targets oligodendrocytes and astrocytes, but not microglia, for infection. LSTc was not detected on either oligodendrocytes or astrocytes, but these cells did express 5$\mathrm{HT}_{2}$ receptors (Figure 7, $\mathrm{H}-\mathrm{K}$ ), similar to findings observed in normal brain. Oligodendrocytes were positive for expression of the late viral protein 1 (VP1), indicating that these cells were lytically infected by JCPyV (Figure 7L).
Although we did not observe $5-\mathrm{HT}_{2 \mathrm{~A}}$-expressing $\mathrm{VP}^{+}$cells (Figure $7 \mathrm{M}$ ), JCPyV-infected glial cells expressing 5- $\mathrm{HT}_{2 \mathrm{~B}}$ and $5-\mathrm{HT}_{2 \mathrm{C}}$ were present in the PML lesions (Figure 7, $\mathrm{N}$ and $\mathrm{O}$ ).

\section{Discussion}

In vitro experiments have shown that for productive host cell infection, JCPyV requires surface expression of the attachment receptor LSTc as well as one of the members of the $5-\mathrm{HT}_{2}$ family, $\mathrm{G}$ protein-coupled receptors required for entry. ${ }^{37,38}$ In the present study, we investigated the in vivo expression of these receptors in human kidney and brain, the main sites of latency/persistence and pathogenesis, respectively, and compared receptor-expression profiles with the pattern of virus attachment. Here, we show that virus 

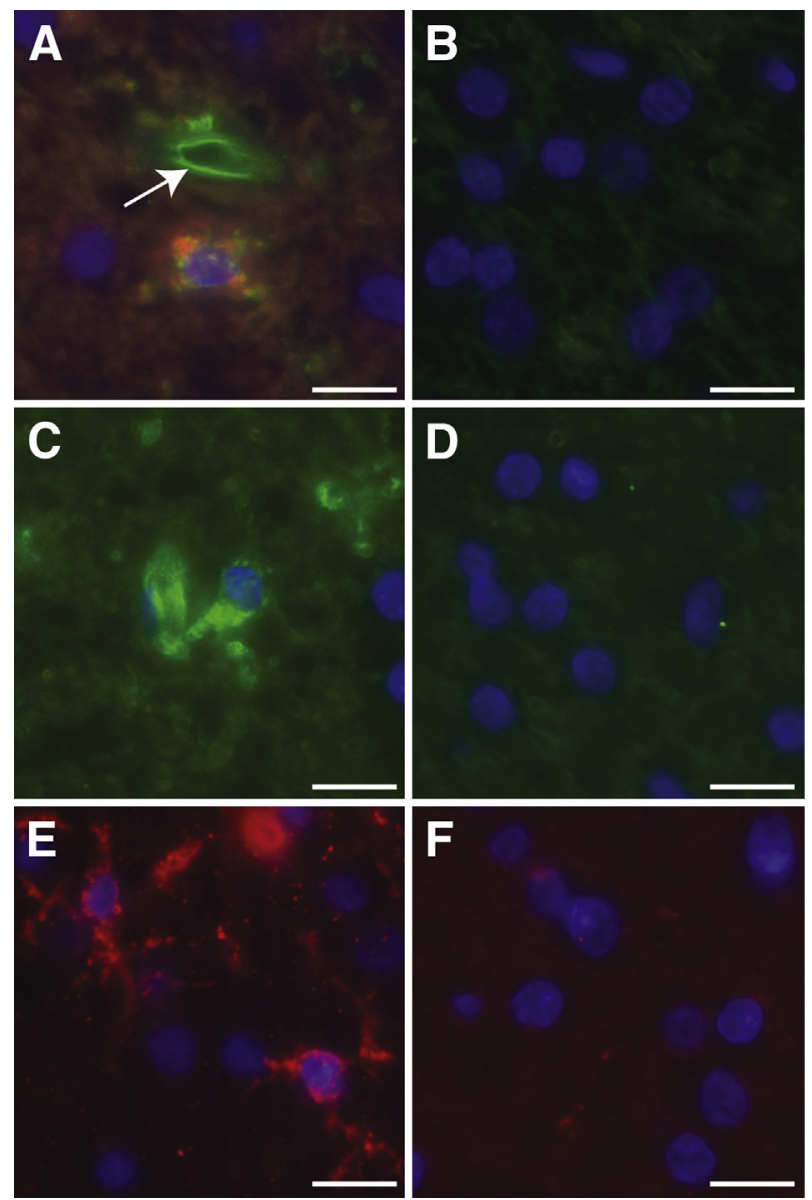

Figure 6 Human polyomavirus (JCPyV) binds to brain endothelium and microglial cells via attachment receptor lactoseries tetrasaccharide c (LSTC). A: Colocalization with CD68 (red) shows that JCPyV-488 binds to microglial cells. Arrow indicates neuroendothelium. B: Treatment with neuraminidase abolishes virus binding. C: Competition with LSTb does not affect JCPyV-488 binding to brain. D: Competition with LSTc abolishes JCPyV-488 binding to brain tissue. E: Polyporus squamosus lectin (PSL; red) labels microglia and neuroendothelium. F: PSL no longer binds to brain tissue following treatment with neuraminidase. Scale bars: $25 \mu \mathrm{m}$.

binding to the plasma membrane depends on the presence of LSTc.

In addition, the attachment and entry receptors were coexpressed in the kidney tubule epithelium and CPE, two cell types that the virus has been shown to infect, whereas in the brain parenchyma, the entry receptors were present on the main targets of JCPyV infection, and the attachment receptors were instead largely expressed on neuroendothelium and cells of myeloid lineage, suggesting potential mechanisms of entry into the CNS. We did not observe qualitative differences in the binding of antibodies, lectins, or virus to tissues from different patients.

\section{JCPyV Attachment to Renal Tubules}

JCPyV binds specifically to the distal tubule epithelium and collecting ducts in the human kidney. JCPyV infection has previously been shown in the tubular epithelium of immunesuppressed patients. By in situ hybridization, JCPyV DNA was detected in the collecting tubules of a PML patient. ${ }^{51}$ JCPyV VP1 protein has been detected in the epithelial tubules in kidneys of AIDS patients ${ }^{52}$ and renal transplant recipients, ${ }^{53-55}$ and one report of a non- PML renal cancer patient described JCPyV in collecting ducts. ${ }^{56}$ Although not nearly as often as the closely related polyomavirus BKPyV, JCPyV can cause JCPyV-associated nephropathy. ${ }^{57,58}$ Here, we show that virus binding is dependent on the virus attachment receptor, as shown by specific LSTc competition assay. The lectin used for detecting LSTc-like sugars not only bound predominantly to distal tubules and collecting ducts but also detected $\alpha 2,6$ sialic acid on kidney endothelium, glomeruli, and Bowman's capsule. However, only minor virus attachment to these nontubular cells was observed after prolonged virus exposure. It is possible that either the lectin is detecting a sugar other than LSTc or that an additional factor is contributing to additional specificity of virus attachment to the distal tubules and collecting ducts. JCPyV entry into cells depends on the presence of $5-\mathrm{HT}_{2}$ receptors, and the distal tubules and collecting ducts express each of these receptors, suggesting that the virus can attach and enter these cells to cause persistent infection and, in some cases, pathogenesis.

\section{Direct Binding of JCPyV to Barriers of the CNS}

To infect cells in the brain and cause neurological disease, JCPyV must cross one of the barriers that protect neural tissue from the periphery, the blood-brain barrier (BBB) and the blood-cerebrospinal fluid barrier (BCSFB), which restrict the passage of cells and microbes between the peripheral circulation, brain, and CSF. How JCPyV crosses these obstacles to the CNS is not yet known. Here, we demonstrate that JCPyV attaches via LSTc directly to neuroendothelial cells that make up part of the BBB. Although the virus binds avidly to the neuroendothelium, these cells are not considered target host cells for JCPyV, and we did not detect entry receptor expression in brain microvascular cells. In rare cases, in situ hybridization experiments have detected JCPyV DNA in brain endothelium of PML patients, ${ }^{59,60}$ and JCPyV infection of cultured human brain microvasculature endothelial cells has been reported in vitro, ${ }^{61}$ but productive JCPyV infection has not been shown in neuroendothelium of human tissue.

The BBB forms an interface between the bloodstream and the CNS and is composed of highly specialized endothelial cells bound by tight junctions, astrocytic endfeet, the capillary basement membrane, and pericytes embedded in this extracellular matrix. The migration of cells from the periphery to the brain parenchyma is highly regulated, and under normal conditions the BBB blocks circulating monocytes from migrating into the brain. However, these structures must be dynamically regulated to allow a small population of lymphocytes engaged in immune surveillance to pass into the brain parenchyma ${ }^{62,63}$ 

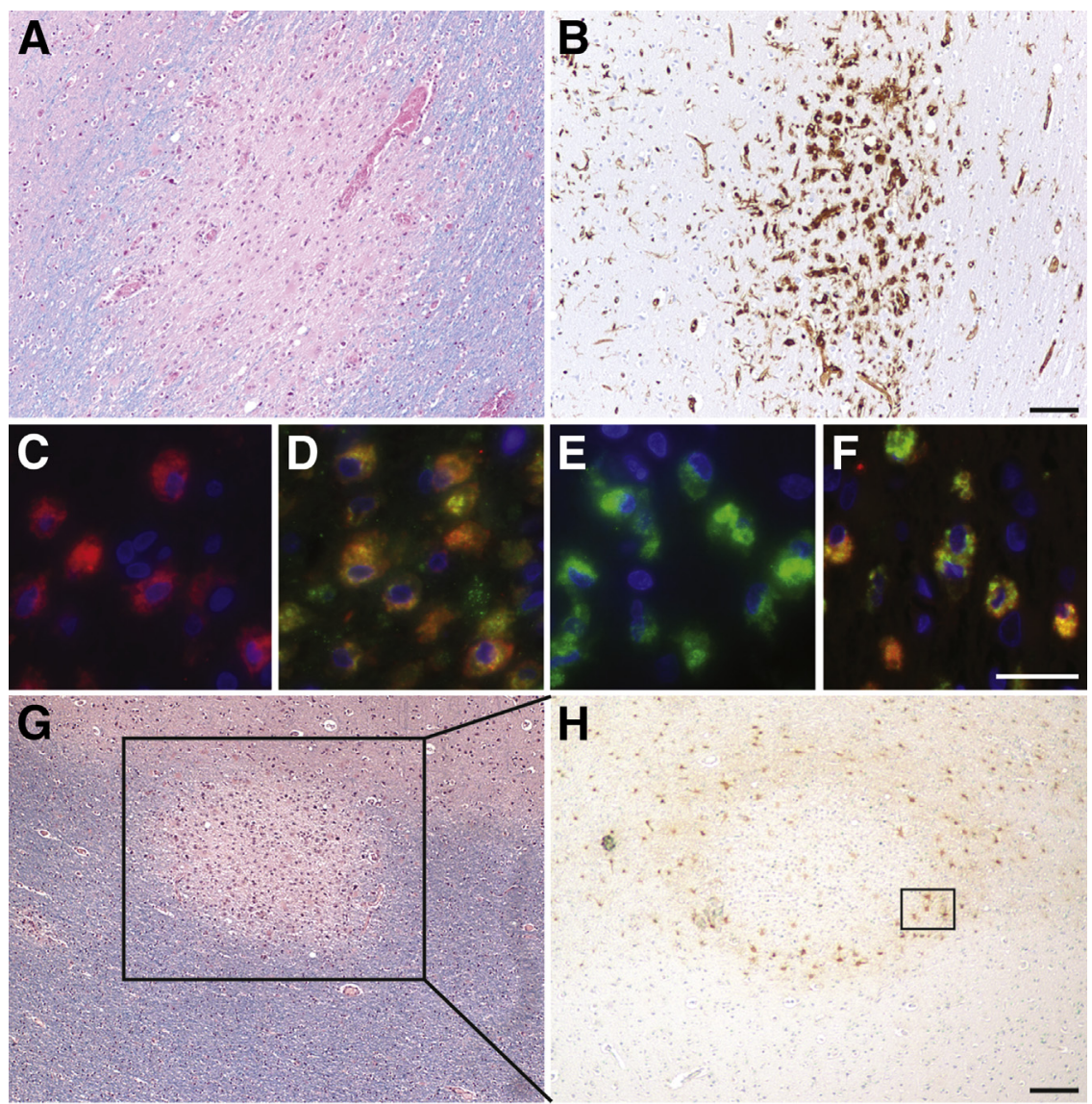

H
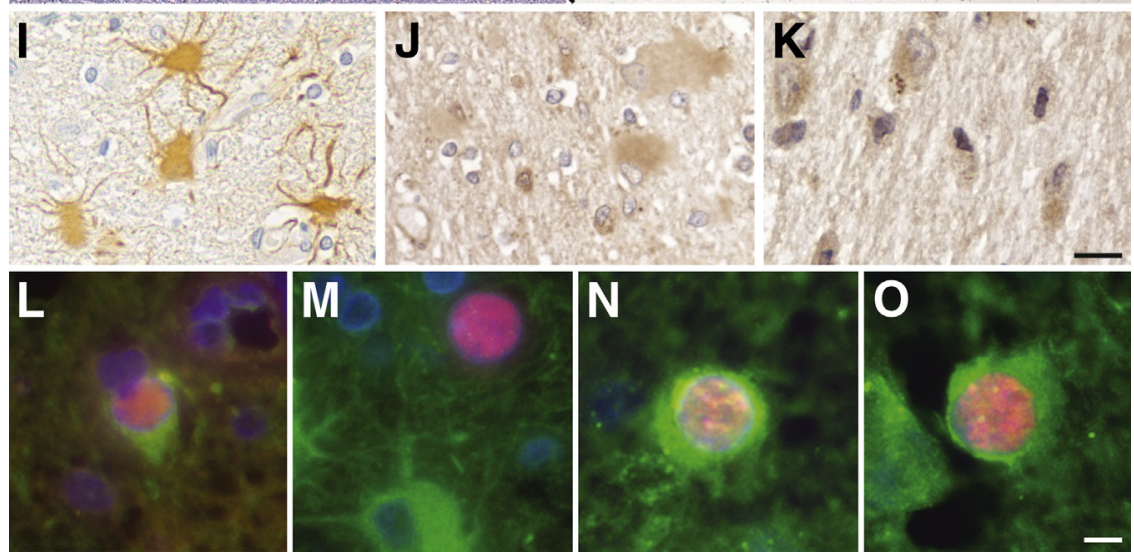

Figure 7 Human polyomavirus (JCPyV) binding, receptor expression, and infection in demyelinating lesions of progressive multifocal leukoencephalopathy (PML). A, B, and G-K: Serial sections of a PML brain were used for immunohistochemistry staining. A: PML brain stained with Luxol fast blue (Sigma) and hematoxylin and eosin (H\&E). B: Serial section of A stained with Polyporus squamosus lectin (PSL). $\mathbf{C}-\mathbf{F}$ and $\mathbf{L}-\mathbf{0}$ : Immunofluorescence staining images of a PML lesion. C: Cells in lesion labeled with PSL (red). D: The PSL ${ }^{+}$cells are $\mathrm{CD}^{+} 8^{+}$(green). E: Cells in lesion labeled with JCPyV-488. F: Cells in lesion colabeled with JCPyV-488 and CD68. G: PML brain stained with Luxol fast blue and H\&E. H: Serial section of same lesion labeled with serotonin (5-HT) 2A. I: Higher magnification of boxed region in $\mathbf{H}, 5-\mathrm{HT}_{2 \mathrm{~A}}$ in PML lesion. J: Cells in PML lesion labeled with 5$\mathrm{HT}_{2 \mathrm{~B}}$. K: Cells in PML lesion labeled with $5-\mathrm{HT}_{2 \mathrm{C}}$. JCPyV-infected cells of a PML lesion express virus entry receptors. $\mathbf{L}-\mathbf{0}$ : Cells in lesion labeled with viral protein (VP)-1 (red) and oligodendrocyte marker carbonic anhydrase II (green) (L), VP1 (red) and $5-\mathrm{HT}_{2 \mathrm{~A}}$ (green) (M), VP1 (red) and 5$\mathrm{HT}_{2 \mathrm{~B}}$ (green) (N), and VP1 (red) and $5-\mathrm{HT}_{2 \mathrm{C}}$ (green) (0). Scale bars: $50 \mu \mathrm{m}(\mathbf{A}, \mathbf{B}, \mathbf{G}$, and $\mathbf{H}) ; 25$ $\mu \mathrm{m}(\mathbf{C}-\mathbf{F}) ; 10 \mu \mathrm{m}(\mathbf{I}-\mathbf{K}) ; 5 \mu \mathrm{m}(\mathbf{L}-\mathbf{0})$. and also circulating monocytes to replace perivascular macrophages. ${ }^{64,65}$ Some pathological conditions such as viral or bacterial infection can disrupt the integrity of the BBB and allow less restricted passage of leukocytes from the systemic circulation into the brain and additional monocytes to enter the brain. ${ }^{66,67}$ During the course of HIV infection, monocytes cross in response to proinflammatory cytokines released by astrocytes and parenchymal myeloid cells. ${ }^{68,69}$ After HIV neuroinvasion, the $\mathrm{BBB}$ is disrupted as a result of loss of transmembrane tight junction integrity in the neuroendothelium ${ }^{70}$ and glycoprotein 120 has been shown to contribute to BBB leakiness, perhaps by increased expression of proteases. ${ }^{71}$ Also, elevated levels of lipopolysaccharide as a result of bacterial infection can compromise the BBB. ${ }^{72,73}$ Lipopolysaccharide can also increase endocytic activity of brain microendothelial cells. ${ }^{74}$ It is possible that JCPyV already bound to the neuroendothelium enters the brain parenchyma after transient disruption of the BBB.

The BCSFB, or choroid plexus, constitutes another potential site of JCPyV entry into the CNS. The BCSFB is formed by a monolayer of polarized epithelial cells enclosing a highly vascularized stroma populated with a variety of cell types, including fibroblasts and macrophages. ${ }^{75}$ Like the endothelial cells of the BBB, the CPE cells express tight junctions and serve as a barrier to separate the CNS from the circulation, and the migration across the BCSFB is restricted. 
However, monocytes ${ }^{76,77}$ and $\mathrm{T}$ cells ${ }^{78}$ have been shown to enter the CNS via the BCSFB in response to injury. It is known that JCPyV entry $5-\mathrm{HT}_{2}$ receptors are expressed in the $\mathrm{CPE}^{79,80}$ and that $5-\mathrm{HT}_{2 \mathrm{C}}$ isolated from the rat choroid plexus is $\mathrm{N}$-glycosylated. ${ }^{81}$ Gene-profiling studies in the rat choroid plexus have shown that chronic stress affects the levels of expression of serotonin $5-\mathrm{HT}_{2}$ family expression. ${ }^{82}$ Here, we show that the CPE expresses both the JCPyV attachment and entry receptors and that the virus interaction with the CPE is LSTc dependent. Recently, JCPyV VP1 was detected in the CPE in a case of JCPyV-associated meningitis, ${ }^{83}$ demonstrating that JCPyV can productively infect these cells. Direct infection of the CPE could allow JCPyV access to brain parenchyma.

\section{Profile of Virus Attachment in the Brain}

In the brain parenchyma, JCPyV binds specifically to microglial cells, the resident immune cells of the CNS. This interaction is mediated by the virus attachment receptor LSTc as virus binding is blocked by competition with LSTc and when the tissue is treated with neuraminidase. Although the microglia can support virus attachment, these cells are not known to be infected by JCPyV. Microglia are longlived tissue macrophages unique to the neural tissue. Under normal conditions, the microglia extend and retract their thin, highly ramified cell processes to continuously monitor the immediate microenvironment. ${ }^{84}$ The processes of each microglial cell do not overlap; each cell surveys its own territory $^{85}$; and some cells, the juxtavascular microglia, directly contact the basal lamina of blood vessels. ${ }^{86}$ On injury to the brain, including infection, inflammation, and trauma, microglial cells undergo a transformation from a resting to an activated state, assuming an ameboid shape and migrating to the site of injury to phagocytose dead cells, clear extracellular debris, and produce cytokines. ${ }^{87-89}$ On damage to the CNS (including in PML lesions), circulating immune cells, including peripherally derived monocytes, macrophages, and dendritic cells, are recruited to the brain parenchyma. Additional myeloid cells in the CNS are found at the junctions where the brain parenchyma meets the rest of the CNS, including perivascular cells, and macrophages and monocyte-derived cells resident in the choroid plexus and meninges. ${ }^{90}$ These cells have distinct embryological origins but share many markers and membrane properties and similar functions, including local immune surveillance and debris removal.

$\mathrm{JCPyV}$ is not known to infect microglia. However, recent reports have shown polyomaviruses interact with $\mathrm{CD} 68^{+}$ cells in other organs. Human polyomavirus KI infects $\mathrm{CD}^{+} 8^{+}$cells in the human lung, ${ }^{91}$ and one study demonstrated that JCPyV and BKPyV viruslike particles are taken up by mouse $\mathrm{CD}^{+} 8^{+}$cells in the mouse liver when administered i.v. ${ }^{92}$ Here we show that JCPyV attaches to the plasma membranes of $\mathrm{CD} 68^{+}$monocyte/macrophages in the stroma of the choroid plexus and meninges. It is possible that the virus enters the brain bound to the outside of an $\mathrm{LSTc}^{+}$cell and then infects oligodendrocytes and astrocytes through a mechanism not yet defined.

$\mathrm{JCPyV}$ is known to infect oligodendrocytes, astrocytes, and neurons. JCPyV infection of oligodendrocytes leads to cell destruction and subsequent demyelinating lesions and loss of neuronal function. Astrocytes have also been shown to support JCPyV replication in the PML brain, and infection of neurons has been described in JCPyV neuropathy and encephalopathy. Here we show that the cell types that are known to be infected by JCPyV express entry receptors that would allow virus entry to permit a productive infection. However, we did not observe the presence of an attachment receptor on these cells, nor did we observe appreciable JCPyV binding to the plasma membrane of these cells. It should be noted that productive viral replication is not solely dependent on the presence of the $5-\mathrm{HT}_{2}$ receptors, as many cell types that express $5-\mathrm{HT}_{2}$ receptors are not infected by JCPyV. Multiple cellular factors, some known and some yet to be discovered, dictate the ability of the virus to productively infect a host cell. Elucidating the factors necessary for permitting productive infection in a host cell is an important component of understanding viral pathogenesis. In our study we observed entry receptor expression in astrocytes, particularly in the reactive astrocytes in the PML brain. It is possible that the virus enters these cells by a mechanism that does not require attachment receptors on the host cell plasma membrane. This concept may explain the evolution of mutants in PML brain that have lost the ability to bind sialic acid. ${ }^{93-95}$

\section{Conclusion}

JCPyV infects approximately half of the population worldwide. ${ }^{1,2}$ After initial infection, the virus persists in the kidney, tonsils, bone marrow, and most likely the brain. After reactivation, the virus can be shed in the urine and usually does not cause disease. However, under conditions of immune suppression, such as HIV/AIDS or treatment with immunemodulatory therapies, JCPyV levels increase and in some patients pathology is observed, either in the brain or, in rare cases, the kidney. It appears that the loss of $\mathrm{T}$ cells and their immune surveillance is necessary for the progression of JCPyV pathogenesis. The mechanisms by which JCPyV enters the CNS remain unknown. Here we demonstrate that virus binds specifically to the neuroendothelial cells of the BBB. It is possible that on disruption of the BBB, either transient, in normal brain, or under conditions of pathogenesis, the virus migrates into the brain parenchyma. JCPyV also binds to the plasma membranes of monocytes that infiltrate the brain on BBB disruption, providing an additional mechanism for JCPyV to reach the parenchyma. An alternative pathway to the CNS is via JCPyV infection of the choroid plexus. Once JCPyV is in the brain, glial cells are exposed and infected by JCPyV by an as-yet undefined 
mechanism. With the increase in immune-suppressing therapies used for addressing autoimmune conditions, more patients are potentially at risk for PML. The identification of the pathways from the environment to the CNS and of agents to block viral infection is essential for developing antiviral therapies for this incurable disease.

\section{Acknowledgments}

We thank the members of the Atwood Laboratory for critical discussion and review of the manuscript and Leila Noble (RIH Molecular Pathology Core) and Nancy Heath (Division of Neuropathology) for technical assistance. pAb 597 antibody was gifted by Dr. Edward Harlow (Harvard Medical School, Boston, MA).

\section{Supplemental Data}

Supplemental material for this article can be found at http://dx.doi.org/10.1016/j.ajpath.2015.04.003.

\section{References}

1. Kean JM, Rao S, Wang M, Garcea RL: Seroepidemiology of human polyomaviruses. PLoS Pathog 2009, 5:e1000363

2. Knowles WA, Pipkin P, Andrews N, Vyse A, Minor P, Brown DW, Miller E: Population-based study of antibody to the human polyomaviruses BKV and JCV and the simian polyomavirus SV40. J Med Virol 2003, 71:115-123

3. Dorries K: Molecular biology and pathogenesis of human polyomavirus infections. Dev Biol Stand 1998, 94:71-79

4. Egli A, Infanti L, Dumoulin A, Buser A, Samaridis J, Stebler C, Gosert R, Hirsch HH: Prevalence of polyomavirus BK and JC infection and replication in 400 healthy blood donors. J Infect Dis 2009, 199:837-846

5. Monaco MC, Jensen PN, Hou J, Durham LC, Major EO: Detection of JC virus DNA in human tonsil tissue: evidence for site of initial viral infection. J Virol 1998, 72:9918-9923

6. Monaco MC, Atwood WJ, Gravell M, Tornatore CS, Major EO: JC virus infection of hematopoietic progenitor cells, primary B lymphocytes, and tonsillar stromal cells: implications for viral latency. $\mathrm{J}$ Virol 1996, 70:7004-7012

7. Grinnell B, Padgett B, Walker D: Distribution of nonintegrated DNA from JC papovavirus in organs of patients with progressive multifocal leukoencephalopathy. J Infect Dis 1983, 147:669-675

8. Newman JT, Frisque RJ: Detection of archetype and rearranged variants of JC virus in multiple tissues from a pediatric PML patient. J Med Virol 1997, 52:243-252

9. Atwood WJ, Amemiya K, Traub R, Harms J, Major EO: Interaction of the human polyomavirus, JCV, with human B-lymphocytes. Virology 1992, 190:716-723

10. Major EO, Amemiya K, Elder G, Houff SA: Glial cells of the human developing brain and B cells of the immune system share a common DNA binding factor for recognition of the regulatory sequences of the human polyomavirus, JCV. J Neurosci Res 1990, $27: 461-471$

11. Caldarelli-Stefano R, Vago L, Omodeo-Zorini E, Mediati M, Losciale L, Nebuloni M, Costanzi G, Ferrante P: Detection and typing of JC virus in autopsy brains and extraneural organs of AIDS patients and non-immunocompromised individuals. J Neurovirol 1999, 5:125-133
12. Bayliss J, Karasoulos T, McLean CA: Immunosuppression increases JC polyomavirus large T antigen DNA load in the brains of patients without progressive multifocal leukoencephalopathy. J Infect Dis 2013, 207:133-136

13. Tan CS, Ellis LC, Wuthrich C, Ngo L, Broge TA Jr, Saint-Aubyn J, Miller JS, Koralnik IJ: JC virus latency in the brain and extraneural organs of patients with and without progressive multifocal leukoencephalopathy. J Virol 2010, 84:9200-9209

14. Gheuens S, Wuthrich C, Koralnik IJ: Progressive multifocal leukoencephalopathy: why gray and white matter. Annu Rev Pathol 2013, 8:189-215

15. Berger JR, Aksamit AJ, Clifford DB, Davis L, Koralnik IJ, Sejvar JJ, Bartt R, Major EO, Nath A: PML diagnostic criteria: consensus statement from the AAN Neuroinfectious Disease Section. Neurology 2013, 80:1430-1438

16. Astrom K, Mancall E, Richardson EP Jr: Progressive multifocal leukoencephalopathy. Brain 1958, 81:93-127

17. Brooks B, Walker D: Progressive multifocal leukoencephalopathy. Neurol Clin 1984, 2:299-313

18. Cinque P, Koralnik IJ, Gerevini S, Miro JM, Price RW: Progressive multifocal leukoencephalopathy in HIV-1 infection. Lancet Infect Dis 2009, 9:625-636

19. Ferenczy MW, Marshall LJ, Nelson CD, Atwood WJ, Nath A, Khalili K, Major EO: Molecular biology, epidemiology, and pathogenesis of progressive multifocal leukoencephalopathy, the JC virusinduced demyelinating disease of the human brain. Clin Microbiol Rev 2012, 25:471-506

20. Grabar S, Lanoy E, Allavena C, Mary-Krause M, Bentata M, Fischer P, Mahamat A, Rabaud C, Costagliola D; Clinical Epidemiology Group of the French Hospital Database on HIV: Causes of the first AIDSdefining illness and subsequent survival before and after the advent of combined antiretroviral therapy. HIV Med 2008, 9:246-256

21. Carson KR, Focosi D, Major EO, Petrini M, Richey EA, West DP, Bennett CL: Monoclonal antibody-associated progressive multifocal leucoencephalopathy in patients treated with rituximab, natalizumab, and efalizumab: a Review from the Research on Adverse Drug Events and Reports (RADAR) Project. Lancet Oncol 2009, 10:816-824

22. Major EO: Reemergence of PML in natalizumab-treated patientsnew cases, same concerns. N Engl J Med 2009, 361:1041-1043

23. Van Assche G, Van Ranst M, Sciot R, Dubois B, Vermeire S, Noman M, Verbeeck J, Geboes K, Robberecht W, Rutgeerts P: Progressive multifocal leukoencephalopathy after natalizumab therapy for Crohn's disease. N Engl J Med 2005, 353:362-368

24. Kleinschmidt-DeMasters BK, Tyler KL: Progressive multifocal leukoencephalopathy complicating treatment with natalizumab and interferon beta-1a for multiple sclerosis. N Eng1 J Med 2005, 353: 369-374

25. Langer-Gould A, Atlas SW, Green AJ, Bollen AW, Pelletier D: Progressive multifocal leukoencephalopathy in a patient treated with natalizumab. N Engl J Med 2005, 353:375-381

26. Zaheer F, Berger JR: Treatment-related progressive multifocal leukoencephalopathy: current understanding and future steps. Ther Adv Drug Saf 2012, 3:227-239

27. Koralnik IJ, Wuthrich C, Dang X, Rottnek M, Gurtman A, Simpson D, Morgello S: JC virus granule cell neuronopathy: a novel clinical syndrome distinct from progressive multifocal leukoencephalopathy. Ann Neurol 2005, 57:576-580

28. Wuthrich C, Dang X, Westmoreland S, McKay J, Maheshwari A, Anderson MP, Ropper AH, Viscidi RP, Koralnik IJ: Fulminant JC virus encephalopathy with productive infection of cortical pyramidal neurons. Ann Neurol 2009, 65:742-748

29. Randhawa P, Baksh F, Aoki N, Tschirhart D, Finkelstein S: JC virus infection in allograft kidneys: analysis by polymerase chain reaction and immunohistochemistry. Transplantation 2001, 71:1300-1303

30. Lautenschlager I, Jahnukainen T, Kardas P, Lohi J, Auvinen E, Mannonen L, Dumoulin A, Hirsch HH, Jalanko H: A Case of Primary 
JC Polyomavirus Infection-Associated Nephropathy. Am J Transplant 2014, 14:2887-2892

31. Drachenberg CB, Hirsch HH, Papadimitriou JC, Gosert R, Wali RK, Munivenkatappa R, Nogueira J, Cangro CB, Haririan A, Mendley S, Ramos E: Polyomavirus BK versus JC replication and nephropathy in renal transplant recipients: a prospective evaluation. Transplantation 2007, 84:323-330

32. Kazory A, Ducloux D, Chalopin JM, Angonin R, Fontaniere B, Moret H: The first case of JC virus allograft nephropathy. Transplantation 2003, 76:1653-1655

33. Shah KV: Polyomaviruses. Fields Virology, 3rd Edition. Edited by Fields BN, Knipe DM, Howley PM. Philadelphia, PA, LippincottRaven, 1996. pp. 2027-2043

34. Dugan AS, Gasparovic ML, Atwood WJ: Direct correlation between sialic acid binding and infection of cells by two human polyomaviruses (JC virus and BK virus). J Virol 2008, 82:2560-2564

35. Komagome R, Sawa H, Suzuki T, Suzuki Y, Tanaka S, Atwood WJ, Nagashima K: Oligosaccharides as receptors for JC virus. J Virol 2002, 76:12992-13000

36. Liu CK, Wei G, Atwood WJ: Infection of glial cells by the human polyomavirus JC is mediated by an $\mathrm{N}$-linked glycoprotein containing terminal alpha 2-6 linked sialic acids. J Virol 1998, 72:4643-4649

37. Neu U, Maginnis MS, Palma AS, Stroh LJ, Nelson CD, Feizi T, Atwood WJ, Stehle T: Structure-function analysis of the human JC polyomavirus establishes the LSTc pentasaccharide as a functional receptor motif. Cell Host Microbe 2010, 8:309-319

38. Elphick GF, Querbes W, Jordan JA, Gee GV, Eash S, Manley K, Dugan A, Stanifer M, Bhatnagar A, Kroeze WK, Roth BL, Atwood WJ: The human polyomavirus, JCV, uses serotonin receptors to infect cells. Science 2004, 306:1380-1383

39. Assetta B, Maginnis MS, Gracia Ahufinger I, Haley SA, Gee GV, Nelson CD, O'Hara BA, Allen Ramdial SA, Atwood WJ: 5-HT2 receptors facilitate JC polyomavirus entry. J Virol 2013, 87: 13490-13498

40. Liu CK, Atwood WJ: Propagation and assay of the JC virus. Methods Mol Biol 2001, 165:9-17

41. Nelson CD, Carney DW, Derdowski A, Lipovsky A, Gee GV, O'Hara B, Williard P, DiMaio D, Sello JK, Atwood WJ: A retrograde trafficking inhibitor of ricin and Shiga-like toxins inhibits infection of cells by human and monkey polyomaviruses. MBio 2013, 4. e0072913

42. Morgello S, Gelman BB, Kozlowski PB, Vinters HV, Masliah E, Cornford M, Cavert W, Marra C, Grant I, Singer EJ: The National NeuroAIDS Tissue Consortium: a new paradigm in brain banking with an emphasis on infectious disease. Neuropathol Appl Neurobiol 2001, 27:326-335

43. Atwood WJ, Wang L, Durham LC, Amemiya K, Traub RG, Major EO: Evaluation of the role of cytokine activation in the multiplication of JC virus (JCV) in human fetal glial cells. J Neurovirol 1995, 1:40-49

44. Henmi C, Sawa H, Iwata H, Orba Y, Tanaka S, Nagashima K: Establishment of an immunoscreening system using recombinant VP1 protein for the isolation of a monoclonal antibody that blocks JC virus infection. Biochem Biophys Res Commun 2005, 327:242-251

45. Howie AJ: Epithelial membrane antigen in normal and proteinuric glomeruli and in damaged proximal tubules. J Pathol 1986, 148: $55-60$

46. Meehan SM, Kraus MD, Kadambi PV, Chang A: Nephron segment localization of polyoma virus large $\mathrm{T}$ antigen in renal allografts. Hum Pathol 2006, 37:1400-1406

47. Mo H, Winter HC, Goldstein IJ: Purification and characterization of a Neu5Acalpha2-6Galbeta1-4Glc/GlcNAc-specific lectin from the fruiting body of the polypore mushroom Polyporus squamosus. J Biol Chem 2000, 275:10623-10629

48. Zhang B, Palcic MM, Mo H, Goldstein IJ, Hindsgaul O: Rapid determination of the binding affinity and specificity of the mushroom Polyporus squamosus lectin using frontal affinity chromatography coupled to electrospray mass spectrometry. Glycobiology 2001, 11: $141-147$

49. Toma V, Zuber C, Winter HC, Goldstein IJ, Roth J: Application of a lectin from the mushroom Polysporus squamosus for the histochemical detection of the NeuAcalpha2,6Galbeta1,4Glc/GlcNAc sequence of N-linked oligosaccharides: a comparison with the Sambucus nigra lectin. Histochem Cell Biol 2001, 116:183-193

50. Maginnis MS, Haley SA, Gee GV, Atwood WJ: Role of N-linked glycosylation of the 5-HT2A receptor in JC virus infection. J Virol 2010, 84:9677-9684

51. Dorries K, ter Meulen V: Progressive multifocal leucoencephalopathy: detection of papovavirus JC in kidney tissue. J Med Virol 1983, 11:307-317

52. Boldorini R, Omodeo-Zorini E, Nebuloni M, Benigni E, Vago L, Ferri A, Monga G: Lytic JC virus infection in the kidneys of AIDS subjects. Mod Pathol 2003, 16:35-42

53. Wen MC, Wang $\mathrm{CL}$, Wang $\mathrm{M}$, Cheng $\mathrm{CH}$, Wu MJ, Chen $\mathrm{CH}$, Shu KH, Chang D: Association of JC virus with tubulointerstitial nephritis in a renal allograft recipient. J Med Virol 2004, 72:675-678

54. Kantarci G, Eren Z, Demirag A, Dogan I, Cakalagaoglu F, Yilmaz G: JC virus-associated nephropathy in a renal transplant recipient and comparative analysis of previous cases. Transpl Infect Dis 2011, 13: 89-92

55. Delbue S, Ferraresso M, Ghio L, Carloni C, Carluccio S, Belingheri M, Edefonti A, Ferrante P: A review on JC virus infection in kidney transplant recipients. Clin Dev Immunol 2013, 2013:926391

56. Aoki N, Kitamura T, Tominaga T, Fukumori N, Sakamoto Y, Kato K, Mori M: Immunohistochemical detection of JC virus in nontumorous renal tissue of a patient with renal cancer but without progressive multifocal leukoencephalopathy. J Clin Microbiol 1999, 37: $1165-1167$

57. Hirsch HH, Kardas P, Kranz D, Leboeuf C: The human JC polyomavirus (JCPyV): virological background and clinical implications. APMIS 2013, 121:685-727

58. Nickeleit V, Mihatsch MJ: Polyomavirus nephropathy in native kidneys and renal allografts: an update on an escalating threat. Transpl Int 2006, 19:960-973

59. Dorries K, Johnson RT, ter Meulen V: Detection of polyoma virus DNA in PML-brain tissue by (in situ) hybridization. J Gen Virol 1979, 42:49-57

60. von Einsiedel RW, Samorei IW, Pawlita M, Zwissler B, Deubel M, Vinters HV: New JC virus infection patterns by in situ polymerase chain reaction in brains of acquired immunodeficiency syndrome patients with progressive multifocal leukoencephalopathy. J Neurovirol 2004, 10:1-11

61. Chapagain ML, Verma S, Mercier F, Yanagihara R, Nerurkar VR: Polyomavirus JC infects human brain microvascular endothelial cells independent of serotonin receptor 2A. Virology 2007, 364:55-63

62. Engelhardt B, Ransohoff RM: Capture, crawl, cross: the T cell code to breach the blood-brain barriers. Trends Immunol 2012, 33: 579-589

63. Hickey WF: Leukocyte traffic in the central nervous system: the participants and their roles. Semin Immunol 1999, 11:125-137

64. Ivey NS, MacLean AG, Lackner AA: Acquired immunodeficiency syndrome and the blood-brain barrier. J Neurovirol 2009, 15: $111-122$

65. Annunziata P: Blood-brain barrier changes during invasion of the central nervous system by HIV-1. Old and new insights into the mechanism. J Neurol 2003, 250:901-906

66. Persidsky Y, Ghorpade A, Rasmussen J, Limoges J, Liu XJ, Stins M, Fiala M, Way D, Kim KS, Witte MH, Weinand M, Carhart L, Gendelman HE: Microglial and astrocyte chemokines regulate monocyte migration through the blood-brain barrier in human immunodeficiency virus-1 encephalitis. Am J Pathol 1999, 155: 1599-1611

67. Petito CK, Adkins B, McCarthy M, Roberts B, Khamis I: CD4+ and $\mathrm{CD} 8+$ cells accumulate in the brains of acquired immunodeficiency 
syndrome patients with human immunodeficiency virus encephalitis. J Neurovirol 2003, 9:36-44

68. Gendelman HE, Ding S, Gong N, Liu J, Ramirez SH, Persidsky Y, Mosley RL, Wang T, Volsky DJ, Xiong H: Monocyte chemotactic protein-1 regulates voltage-gated $\mathrm{K}+$ channels and macrophage transmigration. J Neuroimmune Pharmacol 2009, 4:47-59

69. Didier N, Romero IA, Creminon C, Wijkhuisen A, Grassi J, Mabondzo A: Secretion of interleukin-1beta by astrocytes mediates endothelin-1 and tumour necrosis factor-alpha effects on human brain microvascular endothelial cell permeability. J Neurochem 2003, 86: 246-254

70. Maclean AG, Belenchia GE, Bieniemy DN, Moroney-Rasmussen TA, Lackner AA: Simian immunodeficiency virus disrupts extended lengths of the blood-brain barrier. J Med Primatol 2005, 34:237-242

71. Louboutin JP, Reyes BA, Agrawal L, Van Bockstaele EJ, Strayer DS: HIV-1 gp120 upregulates matrix metalloproteinases and their inhibitors in a rat model of HIV encephalopathy. Eur J Neurosci 2011, 34:2015-2023

72. Wispelwey B, Lesse AJ, Hansen EJ, Scheld WM: Haemophilus influenzae lipopolysaccharide-induced blood brain barrier permeability during experimental meningitis in the rat. J Clin Invest 1988, 82:1339-1346

73. Banks WA, Erickson MA: The blood-brain barrier and immune function and dysfunction. Neurobiol Dis 2010, 37:26-32

74. Banks WA, Kastin AJ, Brennan JM, Vallance KL: Adsorptive endocytosis of HIV-1gp120 by blood-brain barrier is enhanced by lipopolysaccharide. Exp Neurol 1999, 156:165-171

75. Johanson C, Stopa E, McMillan P, Roth D, Funk J, Krinke G: The distributional nexus of choroid plexus to cerebrospinal fluid, ependyma and brain: toxicologic/pathologic phenomena, periventricular destabilization, and lesion spread. Toxicol Pathol 2011, 39: $186-212$

76. Szmydynger-Chodobska J, Strazielle N, Gandy JR, Keefe TH, Zink BJ, Ghersi-Egea JF, Chodobski A: Posttraumatic invasion of monocytes across the blood-cerebrospinal fluid barrier. J Cereb Blood Flow Metab 2012, 32:93-104

77. Shechter R, London A, Schwartz M: Orchestrated leukocyte recruitment to immune-privileged sites: absolute barriers versus educational gates. Nat Rev Immunol 2013, 13:206-218

78. Kunis G, Baruch K, Rosenzweig N, Kertser A, Miller O, Berkutzki T, Schwartz M: IFN-gamma-dependent activation of the brain's choroid plexus for CNS immune surveillance and repair. Brain 2013, 136: $3427-3440$

79. Pasqualetti M, Ori M, Castagna M, Marazziti D, Cassano GB, Nardi I: Distribution and cellular localization of the serotonin type 2C receptor messenger RNA in human brain. Neuroscience 1999, 92: 601-611

80. Nichols DE, Nichols CD: Serotonin receptors. Chem Rev 2008, 108: 1614-1641

81. Backstrom JR, Westphal RS, Canton H, Sanders-Bush E: Identification of rat serotonin 5-HT2C receptors as glycoproteins containing N-linked oligosaccharides. Brain Res Mol Brain Res 1995, 33: $311-318$
82. Sathyanesan M, Girgenti MJ, Banasr M, Stone K, Bruce C, Guilchicek E, Wilczak-Havill K, Nairn A, Williams K, Sass S, Duman JG, Newton SS: A molecular characterization of the choroid plexus and stress-induced gene regulation. Transl Psychiatry 2012, 2: e139

83. Agnihotri SP, Wuthrich C, Dang X, Nauen D, Karimi R, Viscidi R, Bord E, Batson S, Troncoso J, Koralnik IJ: A fatal case of JC virus meningitis presenting with hydrocephalus in a human immunodeficiency virus-seronegative patient. Ann Neurol 2014, 76: $140-147$

84. Nimmerjahn A, Kirchhoff F, Helmchen F: Resting microglial cells are highly dynamic surveillants of brain parenchyma in vivo. Science 2005, 308:1314-1318

85. Ransohoff RM, Cardona AE: The myeloid cells of the central nervous system parenchyma. Nature 2010, 468:253-262

86. Grossmann R, Stence N, Carr J, Fuller L, Waite M, Dailey ME: Juxtavascular microglia migrate along brain microvessels following activation during early postnatal development. Glia 2002, 37: 229-240

87. Davalos D, Grutzendler J, Yang G, Kim JV, Zuo Y, Jung S, Littman DR, Dustin ML, Gan WB: ATP mediates rapid microglial response to local brain injury in vivo. Nat Neurosci 2005, 8:752-758

88. Stence N, Waite M, Dailey ME: Dynamics of microglial activation: a confocal time-lapse analysis in hippocampal slices. Glia 2001, 33: 256-266

89. Haynes SE, Hollopeter G, Yang G, Kurpius D, Dailey ME, Gan WB, Julius D: The P2Y12 receptor regulates microglial activation by extracellular nucleotides. Nat Neurosci 2006, 9:1512-1519

90. Prinz M, Priller J: Microglia and brain macrophages in the molecular age: from origin to neuropsychiatric disease. Nat Rev Neurosci 2014, 15:300-312

91. Siebrasse EA, Nguyen NL, Smith C, Simmonds P, Wang D: Immunohistochemical detection of KI polyomavirus in lung and spleen. Virology 2014, 468-470:178-184

92. Simon-Santamaria J, Rinaldo CH, Kardas P, Li R, Malovic I, Elvevold K, McCourt P, Smedsrod B, Hirsch HH, Sorensen KK: Efficient Uptake of Blood-Borne BK and JC Polyomavirus-Like Particles in Endothelial Cells of Liver Sinusoids and Renal Vasa Recta. PLoS One 2014, 9:e111762

93. Reid CE, Li H, Sur G, Carmillo P, Bushnell S, Tizard R, McAuliffe M, Tonkin C, Simon K, Goelz S, Cinque P, Gorelik L, Carulli JP: Sequencing and analysis of JC virus DNA from natalizumab-treated PML patients. J Infect Dis 2011, 204:237-244

94. Gorelik L, Reid C, Testa M, Brickelmaier M, Bossolasco S, Pazzi A, Bestetti A, Carmillo P, Wilson E, McAuliffe M, Tonkin C, Carulli JP, Lugovskoy A, Lazzarin A, Sunyaev S, Simon K, Cinque P: Progressive multifocal leukoencephalopathy (PML) development is associated with mutations in JC virus capsid protein VP1 that change its receptor specificity. J Infect Dis 2011, 204:103-114

95. Maginnis MS, Stroh LJ, Gee GV, O’Hara BA, Derdowski A, Stehle T, Atwood WJ: Progressive multifocal leukoencephalopathyassociated mutations in the JC polyomavirus capsid disrupt lactoseries tetrasaccharide $\mathrm{c}$ binding. MBio 2013, 4. e00247-13 